\title{
Telomerase promoter mutations in cancer: an emerging molecular biomarker?
}

\author{
João Vinagre \& Vasco Pinto \& Ricardo Celestino \& Marta Reis \& Helena Pópulo \& Paula \\ Boaventura \& Miguel Melo \& Telmo Catarino \& Jorge Lima \& José Manuel Lopes \& Valdemar \\ Máximo \& Manuel Sobrinho-Simões \& Paula Soares
}

\begin{abstract}
Cell immortalization has been considered for a long time as a classic hallmark of cancer cells. Besides telomerase reactivation, such immortalization could be due to telomere maintenance through the "alternative mechanism of telomere lengthening" (ALT) but the mechanisms underlying both forms of reactivation remained elusive. Mutations in the coding region of telomerase gene are very rare in the cancer setting, despite being associated with some degenerative diseases. Recently, mutations in telomerase (TERT) gene promoter were found in sporadic and familial melanoma and subsequently in several cancer models, notably in gliomas, thyroid cancer and bladder cancer. The importance of these findings has been reinforced by the association of TERT mutations in some cancer types with tumour aggressiveness and patient survival. In the first part of this review, we summarize the data on the biology of telomeres and telomerase, available methodological approaches and nonneoplastic diseases associated with telomere dysfunction. In the second part, we review the information on telomerase expression and genetic alterations in the most relevant types of cancer (skin, thyroid, bladder and central nervous system) on record, and discuss the value of telomerase as a new biomarker with impact on the prognosis and survival of the patients and as a putative therapeutic target.
\end{abstract}

Keywords

Telomerase . TERT . Promoter . Mutations . Biomarker . Cancer

Telomeres and telomerase in germinative and somatic tissues

Normal somatic cells are not immortal and dispose of a predetermined limited number of divisions, a phenomenon known as the Hayflick limit. In 1961, Leonard Hayflick demonstrated that in cell cultures, a population of normal human fetal cells could divide around 40 to 60 times before entering into senescence [44]. At the time, the limited replication potential of somatic cells was not fully understood. Years later, the pioneering research of Nobel Prize winners Elizabeth Blackburn, Jack Szostak and Carolyn Greider identified a refined mechanism by which telomeres are shortened at each round of cell division creating a replication limit [9, $36,116]$. Currently, it is well established that telomeres are nucleoprotein complexes at the ends of eukaryotic chromosomes consisting of several repeats of the DNA sequence TTAGGG. The main function of telomeres is to preserve chromosome integrity and genome stability by preventing the chromosome end from degradation $[41,85]$. At each cell division, the telomeric DNA is diminished and telomeres become progressively shorter. Eventually, this loss leads to a 
stop in cell division that forces cell senescence or cell death. This telomere-based mechanism has been proposed to serve as the "clock" that controls the number of times each cell can divide $[41,85]$. In order to achieve immortalization, cells need to overcome the aforementioned barrier. There are two major pathways cells use for maintain telomere lengthening; they either reactivate telomerase, a ribonucleoprotein polymerase, which elongates telomeres by adding hexameric $5^{\prime}$-TTAGGG-3' tandem repeats to the chromosomal ends at the ends, or take advantage of a non-telomerase-dependent (alternative) mechanism, known as ALT [21,59]. Reactivation of telomerase is present in up to $90 \%$ of human cancers, and it allows proliferative cancer cells to maintain telomere length [65]. The remaining 10 to $15 \%$ of human cancers do not have detectable telomerase activity, and a subset of such cases maintain telomere length relying on the ALT mechanism [21]. Heaphy and colleagues performed a comprehensive survey on ALT phenotype in 6,110 primary tumours from 94 different cancer subtypes and observed the presence of ALT in $3.7 \%$ of all tumour specimens but its absence in all benign neoplasms and normal tissues [46]. In this study, the ALT phenotype was identified for the first time in medulloblastoma, oligodendroglioma, schwannoma and glioblastoma [46]. Later on, Heaphy and colleagues demonstrated that ATRX or DAXX mutations are closely associated with the development of ALT in pancreatic endocrine tumours whereas ATRX mutations lead to ALT phenotype in cancers of the central nervous system [45].

Benign neoplasms and normal somatic cells apparently lack telomerase activity but a high level of telomerase activity can be detected in germ cells and in stem cells of selfrenewing tissues [41]. Some putative stem cells, such as the main cells of thyroid solid cell nests, also express telomerase, as we have previously reported $[95,101]$. Most cells that need that to escape telomere shortening rely on the reactivation of telomerase. The telomerase complex comprises several components, the most important being the telomerase RNA component (TERC), the telomerase reverse transcriptase catalytic subunit (TERT) and dyskerin (DKC1 gene) $[22,83,87]$. It was shown in telomerase-negative cells, such as differentiated epithelial cells or human fibroblasts [33], that TERT is the only component necessary to restore the activity of the telomerase complex. The TERT gene is located on chromosome 5 and includes 16 exons that span a $35-\mathrm{kb}$ region. The core promoter of telomerase includes 330 base pairs upstream of the start site, is located in a GC-rich region and contains transcript sites/consensus for transcription elements, indicating a high level of regulation by multiple factors [23] at transcriptional and/or post-transcriptional level [22].

Methods to evaluate telomeres length and telomerase activity

As mentioned above, telomere length is maintained and higher levels of telomerase activity can be detected in cancer cells than in normal somatic cells. The interest in the detection of telomerase activity and/or in telomere length measurement has been increasing since it can represent a powerful tool for the diagnosis of telomerase-related diseases as well as for the understanding of cancer etiopathogenesis and, hopefully, for improving cancer treatment. In order to evaluate the two aforementioned features, several methods and approaches to measure telomere length, telomerase messenger RNA (mRNA) expression and telomerase enzymatic activity have been developed [113]. Herein, we merely provide a summary of the methods available; for a more detailed review, the reader is referred to references [46] and [115]. The traditional telomere restriction fragment (TRF) analysis measures the average length of all telomeres present in a cell population and is the most used technique for 
evaluating telomere length [4]. Based on Southern blotting, TRF involves the use of restriction enzymes to digest genomic DNA and a hybridization step with a telomeric probe [60]. Additional techniques available include: STELA (single telomere elongation length analysis), a very accurate method that can only be used on a sample with a limited number of cells; quantitative PCR, less time consuming but less accurate [7]; Q-FISH (quantitative fluorescent in situ hybridization) which allows specific measurement of chromosome ends with high resolution [20]; and, finally, Flow FISH, a very accurate method that evaluates cells in suspension [5]. The detection of telomerase is mainly based on assays that evaluate telomerase enzymatic activity $[64,129]$. Refinement of these techniques led to a sensitive technique, the telomeric repeat amplification protocol (TRAP). TRAP assay includes the preparation of a protein extract by cell lysis and the addition of a labelled oligonucleotide substrate along with dNTPs, followed by PCR. In the first step of the reaction, if telomerase is active in the extract, it adds a number of telomeric repeats onto the $3^{\prime}$ end of a labelled substrate oligonucleotide; in the second step, the extended products are amplified by PCR using primers, which generates a ladder of products with 6-base increments starting at 50 nucleotides: 50, 56, 62, 68, etc. [59]. TRAP is the most used technique to evaluate telomerase activity due to its high sensitivity but it also has some limitations: it is very time consuming and can generate false-negative results if the PCR step fails [64]. Recent improvements in the TRAP technique avoid the use of radioactive nucleotides [115]; other efforts have been made to refine the protocol in an attempt to still improve its sensitivity and to increase its reliability $[113,129]$.

\section{Telomerase in degenerative diseases}

Three human diseases - dyskeratosis congenita (DC), aplastic anaemia (AA) and idiopathic pulmonary fibrosis (IPF) - are associated to mutations in genes that code for the telomerase components, either TERC or TERT, as well for the following telomerase-associated proteins: DKC1, telomerase Cajal body protein 1, TCAB1 (WRP53 gene), NOLA2 protein (NHP2 gene) and NOP10 protein (NOLA3 gene) [79]. Additionally, one of the six proteins that compose the shelterin complex - TERF1-interacting nuclear factor 2 (TIN2 gene)-has also been associated with autosomal-dominant DC, Hoyeraal Hreidarsson syndrome, Revesz syndrome and AA. Furthermore, some alterations affect proteins which do not have a direct impact on telomerase but concern the telomere such the telomere maintenance complex component 1 protein (CTC1 gene) that is associated to Coats plus syndrome, which is a form of cerebroretinal microangiopathy with calcifications and cysts. Finally, mutations of the regulator of telomere elongation helicase 1 (RTEL1 gene) have been identified in patients with severe autosomal recessive DC [35] (Table 1). DC is a rare inherited disorder characterized by a typical triad of clinical manifestations: skin hyperpigmentation, oral leukoplakia and nail dystrophy [26]. The majority of cases ( $>80 \%$ ) occur in children and are diagnosed usually about the age of ten when the children start presenting bone marrow failure together with the previously described clinical triad. Other symptoms that include indicators of premature ageing, such as pulmonary diseases, dental abnormalities and alopecia, are present in 15-25\% of the cases [79]. Within the DC spectrum, there is the Hoyeraal Hreidarsson syndrome, a multisystemic disorder characterized by mental retardation, microcephaly, intrauterine growth retardation, cerebellar hypoplasia, immunodeficiency and AA [51]. The Revesz syndrome that is characterized by bilateral exudative retinopathy, bone-marrow hypoplasia, nail dystrophy, fine hair, cerebellar hypoplasia and growth retardation is also present in the DC disease 
spectrum [108]. DC is a genetically heterogeneous disease; to date, there are nine genes associated with DC and all of them contribute to telomere maintenance/protection or telomerase function, thus explaining the excessively short telomeres of DC patients. The group of DC genes encompasses the core telomerase component TERT and TERC and the telomerase complex proteins coded by DKC1, WRAP53, NOP10 and NHP2 genes. Other genes include the shelterin complex TIN2 gene, CTC1 and RTEL1 genes [35] (Table 1). AA is a rare and severe bone marrow disorder characterized by hypocelullar bone marrow and low blood cell counts [109]. Similarly to DC, the cases of AA arise from scarcity of haematopoietic progenitor and stem cells [17]. Since patients have shorter telomeres than matched controls, telomerase components constitute an attractive target for genetic screening. Mutations have been detected in the coding sequence of telomerase core components TERT and TERC (Table 1). Occasionally, AA can develop slowly and appear as an atypical form of DC due to bone marrow failure over time [31]. IPF is a rapidly progressive disorder with an autosomal dominant pattern of inheritance and different degrees of penetrance. The symptoms that characterize the disease are chronic cough and shortness of breath due to fibrotic lesions and scarring of the lungs [40]. IPF can co-exist in patients with AA and DC [35]. Like in the aforementioned disorders, IPF patients also have shorter telomeres than age-matched controls [17]. TERT and TERC telomerase component mutations have been found in familial forms of IPF [107]. The human diseases associated with telomerase or telomere dysfunction encompass mainly the above-referred three disorders (and some related syndromes) but there are other rare diseases reported in the literature [35]. Most of them are haematological disorders, such as myelodysplatic syndrome and paroxysmal nocturnal haemoglobinuria [35]. In cases of myelodysplastic syndrome, mutations are considered an extremely rare event and were described in TERC coding region and its promoter [17]. The same mutation, which ablates a transcription factor binding site in the TERC promoter, has also been detected in a case of paroxysmal nocturnal haemoglobinuria [17]. Additional information regarding mutations in degenerative disorders is summarized in Table 1 , and further information can be retrieved on the telomerase disease database (http://telomerase.asu.edu/). 
Table 1 Genes reported to be altered and respective associated diseases thought to reflect telomerase complex dysfunction

\begin{tabular}{|c|c|}
\hline Gene & Associated disease reported in the literature ${ }^{a}$ \\
\hline TERC & $\begin{array}{l}\text { Aplastic anaemia } \\
\text { Autosomal dominant dyskeratosis congenita } \\
\text { Dyspnoea } \\
\text { Hypoplastic myelodysplastic syndrome } \\
\text { Idiopathic pulmonary fibrosis } \\
\text { Leukaemia } \\
\text { Menorrhagia } \\
\text { Myelodysplasia } \\
\text { Paroxysmal nocturnal hemoglobinuria } \\
\text { Refractory anaemia } \\
\text { Thrombocytopenia }\end{array}$ \\
\hline TERT & $\begin{array}{l}\text { Aplastic anaemia } \\
\text { Autosomal dominant dyskeratosis congenita } \\
\text { Autosomal recessive dyskeratosis congenita } \\
\text { Hoyeraal Hreidarsson syndrome } \\
\text { Idiopathic pulmonary fibrosis } \\
\text { Severe pancytopenia }\end{array}$ \\
\hline$D K C l$ & $\begin{array}{l}\text { Hoyeraal Hreidarsson syndrome } \\
\text { X-linked recessive dyskeratosis congenita }\end{array}$ \\
\hline $\begin{array}{l}\text { Nola2 } \\
\text { Nola3 } \\
\text { WRD79 }\end{array}$ & Autosomal recessive dyskeratosis congenita \\
\hline$T I N F 2$ & $\begin{array}{l}\text { Aplastic anaemia } \\
\text { Autosomal dominant dyskeratosis congenita } \\
\text { Hoyeraal Hreidarsson syndrome } \\
\text { Revesz syndrome }\end{array}$ \\
\hline
\end{tabular}

“Adapted from http//telomerase.asu.edu/

\section{Telomerase promoter mutations and cancer}

It has been known for 20 years that high levels of telomerase activity can be detected in cancer cells [59]; this contrasts with the fact that mutations affecting the telomerase coding region appear to be very uncommon in cancer [4]. A rare example of neoplasia presenting mutations in the coding region of telomerase is acute myeloid leukaemia in which few TERT mutations have been identified [17]. However, it should be taken into account that this form of leukaemia can arise from AA and myelodysplatic syndromes in which TERT mutations have been detected [17]. Published simultaneously in the beginning of 2013, two different studies reported mutations in the promoter of the telomerase gene in melanoma [50,53]. We and others reported the presence of recurrent somatic mutations in the telomerase promoter in cancers of the central nervous system (43-51\%), bladder (59-66\%), hepatocellular carcinoma (59\%), thyroid (follicular cell-derived tumours) (10\%), skin (melanoma, $29-73 \%$ ) and tumours originated from tissues with relatively low rates of self-renewal $[58,75,88,121]$. Additionally, other studies reported the association of telomerase promoter mutations to other types of tumours, including atypical fibroxantoma (93\%), pleomorphic dermal sarcoma (76 \%) [39], bladder cancer (65\%) 
$[1,54]$, basal cell carcinoma (78\%), squamous cell carcinoma of the skin (50\%) [110] and clear cell carcinoma of the ovary [124]. In Tables 2 and 3, we summarize the frequency of TERT promoter mutations in human cancers with a high percentage of mutations and in human cancers with absent or low frequency of TERT promoter mutations, respectively. The in vitro biological assessment of the functional consequence of these mutations, studied by promoter luciferase assay, revealed that their presence results in a two to fourfold increase in telomerase expression [50,53]. Since previously published studies reported high levels of TERT expression in the set of tumours with TERT promoter mutations $[70,78,111]$, it is likely that such alterations may represent one of the missing links between telomerase gene regulation/ reactivation.

Telomerase promoter mutations in skin cancers

Telomerase activity has been reported in normal skin by some authors $[43,118,119]$ while other authors suggest that in normal skin, it is a rare event $[52,91]$. Its activation in the epidermis may be related with the need for cell proliferation and damage repair [11]. The shortening of telomeres, on the other hand, is believed to provide a barrier for epidermal cell proliferation (i.e. cancer) [11]. Telomerase activity has been reported in cutaneous melanomas, using the TRAP assay, with increasing values from normal skin to benign nevi and to dysplastic nevi and finally to melanoma [29]. An association between increased telomerase activity and worse prognostic features, namely, ulceration, vascular invasion, mitotic rate and Breslow thickness has been described in melanoma [18, 32, 81, 91, 100]. Furthermore, higher telomerase activity has also been associated with higher proliferation rate and early metastasis [100, 104]. The suppression of telomerase activity in melanoma cell lines induced cellular differentiation and reduced the metastatic ability $[6,30]$. Longer telomere length has been linked with a higher number of nevi per patient and an increased risk for cutaneous melanoma development $[2,8$, $42,86]$. It was proposed that shorter telomere length in nevi limits proliferation and promotes senescence, protecting against malignant transformation $[41,86]$. At variance with the aforementioned reports, Burke and colleagues suggested that telomere length can also be influenced by CDKN2A mutational status (a high-risk melanoma susceptibility gene), sun exposure and pigmentation phenotype and therefore cannot be considered a biomarker to predict melanoma risk per se [12]. Two seminal papers reported high frequency of TERT promoter mutations in familial and sporadic melanoma [50,53]. In the study from Horn and colleagues, a melanomaprone family was investigated through linkage and NGS and a germ-line disease-segregating mutation was identified in the telomerase promoter [50]. Further confirmation was obtained from the same group in a series of cell lines derived from metastatic melanomas, respective metastases and matched primary melanomas that revealed a higher frequency of the mutations in the metastases (74, 85 and $33 \%$, respectively) [50]. Huang and colleagues took a different approach, data mining of whole genome sequencing data, publicly available. They detected the presence of promoter mutations in $89 \%$ of melanoma cases [53]. The mutations clustered mostly, but not exclusively, in two hotspots that are located at -146 and -124 bps distance upstream of the start site ATG [53]. The detected mutations were cytidine to thymidine transitions at a dipyrimidine motif indicating a putative ultraviolet lightinduced damage signature. These mutations generate a new binding consensus for ETS/TCFs transcription factors (CCGG AA) [50,53]. Moreover, it was demonstrated in vitro by luciferase assay that the presence of these mutations lead to a two to fourfold increase of the TERT promoter activity [54]. TERT promoter mutations were not detected in nevi [121] but in $13 \%$ of mucosal melanomas [27]. In primary cutaneous melanomas, TERT promoter mutations were 
found to be associated with BRAF V600E mutations, worse prognostic features and shorter disease free and overall survival [94, 121]. In ocular melanomas, TERT promoter mutations were described in 0 to $32 \%$ of conjunctival melanomas $[25,121]$. Mutations were not detected in uveal melanomas [121]. At variance with the aforementioned data, Dono and colleagues observed a case of uveal melanoma harbouring a TERT promoter mutation that co-existed with GNA11 and EIF1AX mutations [25].

Table 2 Human cancers with high frequency $(>5 \%)$ of TERT promoter mutations

\begin{tabular}{|c|c|c|c|}
\hline Cancer type & Number of mutations (\%) & Range (\%) & References \\
\hline \multicolumn{4}{|l|}{ Nervous system } \\
\hline Astrocytoma $(n=597)$ & $96(16)$ & $(7.7-25)$ & {$[3,57,58,63,121]$} \\
\hline Glioblastoma $(n=1103)$ & $733(66)$ & $(28-84)$ & {$[3,10,57,58,77,89,121]$} \\
\hline Medulloblastoma $(n=700)$ & $154(22)$ & $(19-42)$ & {$[58,63,71,102]$} \\
\hline Oligoastrocytoma $(n=263)$ & $116(44)$ & $(25-53)$ & {$[3,57,58,63]$} \\
\hline Oligodendroglioma $(n=318)$ & $233(73)$ & $(45-79)$ & {$[3,57,58,63,121]$} \\
\hline Other tumours ( $n=792)$ & $45(5.7)$ & $(0-28)$ & {$[34,58,63]$} \\
\hline \multicolumn{4}{|l|}{ Digestive system } \\
\hline Gallbladder carcinoma $(n=164)$ & $14(8.5)$ & $(0-9.1)$ & {$[58,98]$} \\
\hline Hepatocellular carcinoma $(n=366)$ & $206(56)$ & $(44-59)$ & {$[58,88]$} \\
\hline \multicolumn{4}{|l|}{ Endocrine System } \\
\hline \multicolumn{4}{|l|}{ Thyroid cancer } \\
\hline Follicular carcinoma ( $n=207$ ) & $39(19)$ & $(14-36)$ & {$[74-76,80,121]$} \\
\hline Papillary carcinoma $(n=1128)$ & $132(12)$ & $(7.5-25)$ & {$[66,74-76,80,121]$} \\
\hline Poorly differentiated carcinomas $(n=97)$ & $42(43)$ & $(29-52)$ & {$[66,75,80,121]$} \\
\hline Anaplastic carcinoma $(n=130)$ & $57(44)$ & $(33-50)$ & {$[66,74,75,80,121]$} \\
\hline Hürthle cell carcinoma $(n=61)$ & $4(6.6)$ & $(0-16)$ & {$[66,80,121]$} \\
\hline \multicolumn{4}{|l|}{ Eye } \\
\hline Conjunctival melanoma $(n=42)$ & $12(29)$ & $(0-32)$ & {$[38,121]$} \\
\hline \multicolumn{4}{|l|}{ Head and neck } \\
\hline Laryngeal carcinoma $(n=235)$ & $64(27)$ & - & [97] \\
\hline \multicolumn{4}{|l|}{ Reproductive system } \\
\hline Endometrial carcinoma $(n=19)$ & $2(11)$ & & [58] \\
\hline \multicolumn{4}{|l|}{ Ovarian cancer } \\
\hline Clear cell carcinoma ( $n=245$ ) & $39(16)$ & $(16-17)$ & {$[58,124]$} \\
\hline \multicolumn{4}{|l|}{ Skin } \\
\hline Basal cell carcinoma $(n=270)$ & $125(46)$ & $(39-74)$ & {$[37,94,110]$} \\
\hline Cutaneous melanoma ( $n=591)$ & $215(36)$ & $(12-71)$ & {$[27,47,50,53,69,94,121]$} \\
\hline Mucosal melanoma $(n=53)$ & $7(13)$ & & [27] \\
\hline Metastatic melanoma $(n=92)$ & $72(78)$ & $(67-85)$ & {$[27,50]$} \\
\hline Squamous cell carcinoma $(n=76)$ & $32(42)$ & $(9.1-50)$ & {$[37,58,110]$} \\
\hline \multicolumn{4}{|l|}{ Soft tissue and pleura } \\
\hline Atypical fibroxanthomas $(n=27)$ & $25(93)$ & & [39] \\
\hline Chondrosarcoma $(n=2)$ & $1(50)$ & & [58] \\
\hline Fibrosarcoma $(n=3)$ & $1(33)$ & & [58] \\
\hline Malignant peripheral nerve sheath tumour $(n=38)$ & $2(5.3)$ & $(0-6)$ & {$[58,62]$} \\
\hline Malignant pleural mesothelioma $(n=71)$ & $8(11)$ & & [117] \\
\hline Myxoid liposarcoma $(n=63)$ & $48(76)$ & $(74-79)$ & {$[58,62]$} \\
\hline Pleomorphic dermal sarcoma $(n=34)$ & $26(76)$ & & [39] \\
\hline Solitary fibrous tumour $(n=41)$ & $6(15)$ & $(13-20)$ & {$[58,62]$} \\
\hline \multicolumn{4}{|l|}{ Kidney and urinary tract } \\
\hline Bladder carcinoma $(n=1447)$ & $1028(71)$ & $(47-85)$ & {$[1,54,58,77,99,121,125]$} \\
\hline Renal cell carcinoma $(n=159)$ & $12(7.5)$ & $(0-9.2)$ & {$[121,123,125]$} \\
\hline Renal pelvic carcinoma $(n=16)$ & $10(63)$ & $(60-64)$ & {$[123,125]$} \\
\hline Transitional carcinoma of the ureter $(n=9)$ & $1(11)$ & & [123] \\
\hline
\end{tabular}


Table 3 Human cancers with absent or very low frequency of TERT promoter mutations

\begin{tabular}{|c|c|c|c|}
\hline Cancer type & Number of mutations (\%) & Range (\%) & References \\
\hline \multicolumn{4}{|l|}{ Breast } \\
\hline Breast carcinoma $(n=88)$ & 0 & - & [58] \\
\hline \multicolumn{4}{|l|}{ Nervous system } \\
\hline Spinal ependymoma $(n=9)$ & 0 & - & [58] \\
\hline \multicolumn{4}{|l|}{ Digestive system } \\
\hline Colorectal adenocarcinoma $(n=22)$ & 0 & - & [58] \\
\hline Fibrolamellar hepatocellular carcinoma $(n=12)$ & 0 & - & [58] \\
\hline Gastrointestinal stromal tumour $(n=45)$ & 0 & - & {$[58,121]$} \\
\hline Gastric carcinoma $(n=468)$ & $2(0.43)$ & - & {$[73,98]$} \\
\hline Hepatoblastoma $(n=3)$ & 0 & - & [58] \\
\hline Pancreatic acinar carcinoma $(n=25)$ & 0 & - & [58] \\
\hline Pancreatic ductal adenocarcinoma $(n=24)$ & 0 & - & [58] \\
\hline Pancreatic endocrine tumour $(n=68)$ & 0 & - & [58] \\
\hline \multicolumn{4}{|l|}{ Endocrine system } \\
\hline Medullary thyroid carcinoma $(n=158)$ & 0 & - & {$[58,74,75,80,121]$} \\
\hline Phacochromocytoma $(n=17)$ & 0 & - & [121] \\
\hline \multicolumn{4}{|l|}{ Eye } \\
\hline Ocular melanoma $(n=25)$ & 0 & - & [121] \\
\hline Uveal melanoma $(n=118)$ & $1(0.85)$ & $(0-2.0)$ & {$[25,38,121]$} \\
\hline \multicolumn{4}{|l|}{ Head and neck } \\
\hline Esophageal adenocarcinoma $(n=90)$ & 0 & - & [120] \\
\hline Esthesioneuroblastoma $(n=11)$ & 0 & - & [58] \\
\hline Squamous cell carcinoma $(n=405)$ & $17(4.2)$ & $(0-17)$ & {$[50,58,128]$} \\
\hline \multicolumn{4}{|l|}{ Hacmatopoietic system } \\
\hline Acute myeloid leukaemia $(n=48)$ & 0 & - & [58] \\
\hline Chronic lymphoid leukacmia $(n=15)$ & 0 & - & [58] \\
\hline Chronic myeloid leukaemia $(n=6)$ & 0 & - & [58] \\
\hline \multicolumn{4}{|l|}{ Reproductive system } \\
\hline \multicolumn{4}{|l|}{ Ovarian cancer } \\
\hline Endometrioid carcinoma $(n=43)$ & 0 & - & [124] \\
\hline High-grade serous carcinoma $(n=80)$ & 0 & - & [124] \\
\hline Low-grade serous carcinoma $(n=41)$ & $2(4.9)$ & $(3.3-13)$ & {$[58,124]$} \\
\hline Prostate carcinoma $(n=47)$ & 0 & - & {$[58,125]$} \\
\hline Testicular carcinoma $(n=17)$ & 0 & - & [125] \\
\hline \multicolumn{4}{|l|}{ Uterine cervix cancer } \\
\hline Endocervical adenocarcinoma $(n=25)$ & 0 & - & [124] \\
\hline Squamous cell carcinoma $(n=75)$ & $3(4.0)$ & $(3.7-4.5)$ & {$[58,124]$} \\
\hline \multicolumn{4}{|l|}{ Uterine corpus cancer } \\
\hline Endometrioid carcinoma $(n=24)$ & 0 & - & [124] \\
\hline Leiomyosarcoma $(n=22)$ & 0 & - & [124] \\
\hline Serous carcinoma $(n=12)$ & 0 & - & [124] \\
\hline \multicolumn{4}{|l|}{ Soft tissues and pleura } \\
\hline Alveolar thabdomyosarcoma $(n=7)$ & 0 & - & [58] \\
\hline Alveolar soft part sarcoma $(n=6)$ & 0 & - & [62] \\
\hline Angiosarcoma $(n=9)$ & 0 & - & [62] \\
\hline Cholangiosarcoma $(n=28)$ & 0 & - & [58] \\
\hline Clear cell sarcoma $(n=5)$ & 0 & - & [62] \\
\hline Central/conventional chondrosarcoma $(n=9)$ & 0 & - & [58] \\
\hline Dedifferentiated liposarcoma $(n=61)$ & 0 & - & [62] \\
\hline
\end{tabular}




\begin{tabular}{|c|c|c|c|}
\hline Cancer type & Number of mutations (\%) & Range (\%) & References \\
\hline Dermatofibrosarcoma protuberans $(n=10)$ & 0 & - & [62] \\
\hline Embryonal rhabdomyosarcoma $(n=8)$ & 0 & - & [58] \\
\hline Epithelioid sarcoma $(n=4)$ & 0 & - & [62] \\
\hline Extraskeletal myxoid chondrosarcoma $(n=11)$ & 0 & - & {$[58,62]$} \\
\hline Leiomyosarcoma $(n=30)$ & 0 & - & {$[58,62]$} \\
\hline Low-grade fibromyxoid sarcoma $(n=18)$ & 0 & - & {$[58,62]$} \\
\hline Mesothelioena $(n=4)$ & 0 & - & [58] \\
\hline Myxofibrosarcoma $(n=27)$ & 0 & - & [62] \\
\hline Osteosarcoma $(n=23)$ & $1(4.3)$ & - & [58] \\
\hline Pleomorphic liposarcoma $(n=15)$ & 0 & - & [62] \\
\hline Synovial sarcoma $(n=41)$ & $1(2.4)$ & $(0-4.0)$ & {$[58,62]$} \\
\hline Undifferentiated pleomorphic sarcoma $(n=50)$ & 0 & - & {$[58,62]$} \\
\hline Well-differentiated liposarcoma $(n=10)$ & 0 & - & [58] \\
\hline
\end{tabular}

TERT promoter mutations are frequent in non-melanoma skin cancer, ranging from 39 to $74 \%$ in sporadic basal cell carcinomas (BCC) $[37,94,110]$ and present in up to $50 \%$ of cases of squamous cell carcinoma (SCC) $[37,110]$.Telomerase activity has been detected in BCC using TRAP assay both in tumour and tumour-free margins, varying between 20 and $100 \%$, with less activity in the latter [29]. In the tumour-free margins, telomerase activity was found to be more prevalent in sun-exposed skin $[105,119]$. In SCC, the data are scarce: Ueda and colleagues found telomerase activity in $100 \%$ of the cases of a small series $(n=8)$ [119]. Few studies have examined the association between telomere length and skin cancer [2]. Some studies found no significant association between telomere length in peripheral blood leukocytes (PBL) and risk of nonmelanoma skin cancer, either in BCC (two independent sets) [68] or in SCC [42,68]. In contrast, other authors found that longer telomeres in $\mathrm{PBL}$ are protective for $\mathrm{BCC}[2,86]$ and SCC [2]. Telomere length has also been evaluated by fluorescent in situ hybridization (FISH) showing that higher telomere length in BCC is significantly higher than in SCC [93].

Telomerase promoter mutations in thyroid carcinomas

Thyroid tissue is a conditionally renewing tissue that proliferates rarely in adult life. In line with this, telomerase activity in normal thyroid samples is almost absent, being detected in less than $7 \%$ of cases $[16,114]$. On the other hand, telomerase activity was consistently reported in a specific population of thyroid cells-the solid cell nests (SCNs) which are considered to represent embryonic remnants of the ultimobranchial body $[95,101]$. Thyroid carcinomas apparently display less frequent telomerase activation than most human carcinomas. A wide range of frequencies have been reported [16]; in average, it seems that two thirds of thyroid carcinomas display telomerase activation that is more frequent in the undifferentiated (anaplastic) than in differentiated carcinomas [16]. When the results obtained by several authors are combined, telomerase activity occurs in $48 \%$ of papillary thyroid carcinomas (PTC) and $71 \%$ of follicular thyroid carcinomas (FTC). A TERT copy number gain was described in familial PTC [14], but this finding was not confirmed in another series [55]. A recent study by Capezzone and colleagues reported telomerase activity in most sporadic and familial malignant thyroid tumours as well as in some adenomas [15]. Telomerase activity was not observed in hyperplastic nodules or in normal thyroid tissue from patients with sporadic PTC [15]. In summary, the aforementioned findings suggest that telomerase activity may be associated with a more aggressive clinical behaviour of thyroid tumours. Recently, somatic mutations in the promoter region of TERT were 
reported in thyroid tumours $[66,74,75,121]$. In a large series of 469 follicular cell-derived thyroid carcinomas (FCDTC), TERT promoter mutations were found in $7.5 \%$ of PTC, $17.1 \%$ of FTC, $29.0 \%$ of poorly differentiated thyroid carcinomas (PDTC) and $33.0 \%$ of anaplastic thyroid carcinomas (ATC) [80]. This stepwise increase in the frequency of TERT promoter mutations from well to poorly differentiated and undifferentiated carcinomas was also reported in other studies $[66,74]$ (Table 2). TERT promoter mutations were not detected in normal thyroid tissue, benign lesions or medullary thyroid carcinoma (MTC). Moreover, very few tumours with oncocytic features harbouring TERT promoter mutations have been reported, and no mutations were detected in a small series of papillary thyroid microcarcinoma nor in tumours from individuals exposed to the Chernobyl accident $[58,77,121]$. The majority (about $80 \%$ ) of mutated cases presented the $-124 \mathrm{G}>\mathrm{A}$ mutation. In PTC, TERT promoter mutations were significantly more frequent in BRAF-mutated tumours than in BRAF wild-type tumours [74, 75, 80, 121]. The TERT promoter mutations were associated with increased mRNA expression, and this increase was particularly pronounced in tumours harbouring both BRAF and TERT promoter mutations [121]. Two studies analysed the relationship between TERT promoter mutations, clinico-pathological features and outcome. TERT promoter mutations were significantly associated with older age at diagnosis [74, 80], larger tumour size and higher stage [80]. TERT promoter mutations were also found to be an independent predictor of distant metastases and disease persistence at the end of follow-up in differentiated thyroid carcinomas (DTC) [80]. Patients with TERT promotermutated tumours were submitted to more radioiodine treatments with higher doses as well as to other treatment modalities including surgery, external beam irradiation and/or treatment with tyrosine-kinase inhibitors [80]. TERT promoter mutations were significantly associated with disease-specific mortality in the whole FCDTC group; this association held true if the subgroups of patients with DTC, PTC or FTC were independently considered [80]. In DTC, the prognostic value of TERT promoter mutations for disease-specific mortality was independent of age and gender [80]. Altogether, the aforementioned findings indicate that TERT promoter mutations are a major indicator of poor outcome in DTC. The two studies on record on MTC $[59,123]$ did not reveal TERT promoter mutations in this subtype of thyroid carcinoma.

Telomerase promoter mutations in bladder carcinomas

The putative role of telomerase in bladder carcinoma $(\mathrm{BC})$ has been a matter of interest in the last two decades. Using TRAP assay, telomerase activity has been evaluated in BC; telomerase activity was detected in the majority of the studied tumours in contrast to the absence of activity in the respective normal counterpart samples $[70,90]$. In some series, telomerase activity was associated with lower grade and lower stage BC $[84,90]$. Other studies pointed out that both telomerase activity [70] and telomerase expression [126] are associated with higher stage and higher grade [70,90]. Preliminary evidence obtained in cell lines suggest that BC might have TERT promoter mutations [53]. These early results motivated us and others to search for similar events in bladder tumour samples. Similar to cell lines, the same TERT promoter mutations were detected frequently in BC, with a prevalence ranging from 47 to $85 \%$ (Table 2$)[1,54,61,77,99$, $121,125]$. These results rank TERT promoter mutations as one of the most frequent genomic events, possibly the most frequent, in $\mathrm{BC}[1,54,61,77,99,121,125]$. TERT mutations were significantly more frequent among FGFR3 mutant tumours [1]. Wu and colleagues reported a significant co-occurrence of TERT promoter mutations and TP53/RB1 inactivating somatic mutations [125] indicating that both mutations may cooperatively contribute to the progression of BC [125]. Conflicting results have been reported on the association between TERT promoter 
mutations and clinical stage and/or grade of bladder tumours. Wu and colleagues found that TERT promoter mutations are more prevalent in muscle invasive (MI) than in non-muscle invasive (NMI) tumours and also more prevalent in $\mathrm{BC}$ patients with advanced tumour stages (T2-4) than in those with low stage tumours (Ta or T1) [125]. At variance with this, another report found no association between mutation status and stage or grade of BC [54]. Similar results were reported by Allory and colleagues who did not find any differences between NMI and $\mathrm{MI} B C$ in two independent sets of tumours [1]. Similarly to stage and grade, diverging results were obtained on the association between TERT promoter mutation and prognosis. One group reported that the survival rate of patients with TERT mutations was significantly lower than that of patients without mutations [125], whereas another group found no association between clinical outcome and mutation status [1]. An interesting observation was reported by Rachakonda and colleagues who proposed that a common polymorphism, rs 2853669 within a pre-existing Ets2 binding site in the TERT promoter, acts as a modifier of the effect of the mutations on survival and tumour recurrence [99]. The patients with the mutation presented poorer survival in the absence than in the presence of the polymorphism. The mutation in the absence of the variant allele was highly associated with disease recurrence in patients with Tis, Ta and T1 tumours [99]. These results may help to explain some of the divergence reported in studies relating TERT promoter mutations and prognosis of patients with BC. As it was previously noticed, several observations support a model in which TERT somatic mutations are an early event in urothelial carcinogenesis, including their occurrence in a small fraction of subjects with precursor lesions, their presence in tumours of both papillary and invasive features and their low level of intraindividual heterogeneity when analysing multiple tumour regions $[1,58]$. TERT promoter mutations may potentially be used as urinary biomarker; several studies have already performed preliminary evaluations of the feasibility, sensibility and specificity of such procedure $[1,54]$. Prospective studies based upon series are necessary to further assess the clinical utility of the detection of TERT promoter mutations in urine.

Telomerase promoter mutations in central nervous system tumours

Central nervous system (CNS) often have TERT promoter mutations competing favourably in this aspect with most other types of human cancer [58, 121]. Among CNS tumours, gliomas are those displaying by far the highest frequency of TERT mutations which can also be detected at lower frequencies in medulloblastoma and meningioma [63]. Within gliomas, the percentage of cases with TERT promoter mutations differs according to the histopathological type of tumour. TERT promoter mutations are detected in the majority of cases of glioblastoma multiforme (GBM) [World Health Organization (WHO) Grade IV] which is the most frequent and aggressive form of glioma and in oligodendrogliomas (WHO Grade II and III), in contrast to astrocytoma (WHO Grades I, II and III) and ependymoma (WHO Grades I, II and III), in which only a small percentage of the tumours harbour such mutations (Table 3) [63, 121]. Furthermore, the percentage of TERT promoter mutations in oligoastrocytomas, gliomas with a mixed origin, is intermediate between that of oligodendrogliomas and astrocytomas [58]. These findings fit with the reported data on telomerase activity in gliomas which is considerably higher in GBM (50-89\%) and oligodendrogliomas (75-100\%), than in astrocytomas $(0-45 \%)[49,67,106]$. The low frequency of TERT promoter mutations and telomerase activity in grades II and III astrocytomas can be explained by the high prevalence of ATRX mutations, one of the most frequent mutations in this type of glioma [56]. It is known that ATRX mutations trigger ALT in astrocytoma cells and it has been shown that this alternative mechanism is frequently activated in astrocytomas, allowing 
telomere maintenance without the need for telomerase reactivation [48]. In line with this, the frequency of TERT promoter mutations in secondary GBMs (that arise from the progression of lower grade astrocytomas) is considerably lower than in primary GBMs (that appear de novo) [89]. TERT promoter mutations are rare in paediatric tumours of the CNS [63]. In medulloblastomas that typically develop in children, TERT promoter mutations are mainly detected in tumours of the group of older patients and are associated with sonic hedgehog and WNT mutations [102]. Upregulation of TERT expression in paediatric brain tumours was associated with hypermethylation of the TERT promoter, rather than with TERT promoter mutations [19]. These findings are consistent with the fact that the cells, from which paediatric CNS tumours are thought to originate, still have activated telomerase which obviates the need for activation of TERT through promoter mutation. Although ATRX and TERT promoter mutations provide an explanation for the maintenance of telomere length in most gliomas, TERT upregulation was also reported to occur in a subset of gliomas without TERT promoter mutations or ATRX mutations through an as yet unidentified mechanism [58]. Finally, it is worth noting that, previous to the discovery of TERT promoter mutations in gliomas, some studies had reported an association between SNPs in the TERT gene and an increased risk of glioma development $[112,127]$.

Telomerase promoter mutations in other tumour types

In Tables 2 and 3, we have summarized the data on record on the frequency of TERT promoter mutations in tumours from almost every site. For the sake of simplicity, we divided the tumours into those with a high frequency of mutations ( $>5 \%$, Table 2 ) and tumours with no mutations or with a very low frequency of TERT promoter mutations (described by Killela and colleagues, TERT promoter mutations can be relevant in tissues with relatively low rates of selfrenewal [58], an association that fits with the findings in follicular cell-derived thyroid cancer and gliomas. In these two settings (thyroid cancer and gliomas), TERT promoter mutations are associated with a guarded prognosis of the patients harbouring the tumours and probably represent late events of the oncogenic process. On the other hand, TERT promoter mutations can also result from environmental factors such as ultraviolet radiation and chemical carcinogens as suggested by their high frequency in melanoma, basal cell carcinoma and bladder and tongue carcinomas. In this second setting, TERT promoter mutations appear to be an early tumorigenic event and do not carry major prognostic value, with the exception of melanoma. Why clear cut differences exist in the frequency of TERT promoter mutations in tumours of the same system (e.g. hepatocellular carcinoma versus pancreatic carcinoma) remains to be clarified, although there is enough evidence to claim that the high or low prevalence of the mutations appears to be histotype- rather than site-associated. For instance, the high frequency in transitional carcinoma of the bladder and renal pelvis is in contrast to low frequency/absence in kidney carcinoma and the extremely low frequency/absence in adenocarcinomas of every organ of the gastrointestinal tract (Tables 2 and 3).

Telomerase as a therapeutic target

Several therapy strategies have been suggested to control TERT expression in tumours, mainly using small molecule inhibitors, gene therapy approaches and immunotherapy (reviewed in [82]). Inhibition of enzymatic activity with small synthetic molecules allows the disruption of the replicative capacity of cancer cells; in this way, it is though that normal somatic cells will not be 
affected due to the absence of TERT activity. In vitro studies showed that BIBR1532, a noncompetitive inhibitor of both TERT and TERC [92], leads to cellular senescence reducing proliferation and telomere length [24] and is cytotoxic in high doses [28]. Additionally, a marked reduction of the tumorigenic potential of tumour cells treated with BIBR1532 was observed in a mouse xenograft model [24], with no adverse side effects and uncomplicated oral administration of the drug. BIBR1532 is one of the most promising TERT specific-inhibitors to date. Other small synthetic molecules-G-quadruplex ligands, such as BRACO19, RHSP4 and telomestatin-are promising drugs that can be used for TERT targeting therapies [103]. However, clinical testing of some of these molecules has been hampered due to the toxic characteristics of the compounds [82]. Cancer cells with TERT activity can be directly targeted by introducing suicide genes or oncolytic viruses driven by the TERT or TERC promoters, or the inhibition of TERT or TERC activity targeting their RNAs. In the latter strategy, antisense oligonucleotides, small interfering RNAs and ribozymes can be applied for inhibition of TERT activity. GRN163L (also known as imetelstat) is the most studied antisense oligonucleotide that causes TERT inhibition and telomere shortening in cancer cell lines derived from different organs [13]. This compound leads to apoptosis of cells and to inhibition of tumour growth, and it is being used in clinical trials of several cancer types [13]. DNA vaccines (immunotherapy) have been used to generate protective immunity against tumours in several models [96]. The presence of TERT activity in many human cancers turns TERT a tumour-associated antigen suitable for cancer immunotherapy. Contrary to other target antigens, as carcinoembryonic antigen (CEA) and melanoma-associated antigen, TERT-based immunotherapy may be applied to a wide range of malignancies due to the highly frequent TERT-altered expression [122]. In vitro and in vivo studies showed tumour regression using TERT-based vaccination approaches (reviewed in [72]). Different peptides have been used to induce anti-TERT immune response [13] and vaccination using the 1540-548 peptide showed anti-tumour responses in cancer [122]. Several preclinical studies using TERT peptides are being conducted (reviewed in [103]). GV1001, GRNVAC 1 and Vx-001 are the most promising vaccines available to date.

\section{Future perspectives}

The implication of telomerase in human diseases has been studied for a long time and firmly established in a few models of degenerative diseases. In cancer, telomerase dysfunction has been perceived as a potential mechanism for carcinogenesis although the underlying mechanisms remained elusive. The recent identification of telomerase promoter mutations in several types of neoplasia fostered the respective research, and in less than a year, numerous studies have been published reporting similar alterations in many cancer models (Tables 2 and 3). In several relevant cancer types, telomerase promoter mutations seem to constitute a new biomarker for prognosis with potential applications in pre-surgical diagnosis and in the followup of the patients. Low-grade bladder cancers represent a good example on how such finding can represent an added value from a clinical standpoint. Up to $70 \%$ of lowgrade non-invasive bladder tumours recur, and long-term cystoscopic surveillance is the current standard of care. This procedure is expensive and time consuming and carries significant morbidity. The noninvasive evaluation of telomerase promoter mutations in urine may provide diagnostic information, independent of routine cytology, and most importantly, may identify low-grade tumours, which are difficult to identify by cytological examination alone. Whenever dealing with a recurrence, a non-invasive diagnostic test that also serves as a surveillance method will probably represent an attractive alternative for patients, taking into consideration the 
limitations of the technique. A preliminary evaluation of the diagnostic usefulness of the detection of TERT promoter mutations was already performed in urine samples, and the results indicate that such detection may serve as a biomarker of early disease and recurrence $[1,54]$. Moving to a trendier subject, it seems extremely interesting to evaluate whether or not TERT promoter mutations can be detected in tumour-circulating DNA from cell-free fragments in body fluids. In the affirmative case, this process may represent a major advance in the follow-up of cancer patients. Despite the large amount of information collected in these recent years, more questions than answers remain at present with regard to the role of telomerase involvement in carcinogenesis. A novel mechanism for telomerase re-activation and/ or re-expression was discovered; this mechanism, together with ALT, represents the two major pathways for telomere length maintenance. Besides them, other mechanisms may modulate telomerase expression, such as novel forms of transcriptional regulation or epigenetic alterations. We think it is the appropriate time to study large series with robust clinicopathological data and to search for correlations that may establish or rule out the prognostic value of TERT promoter mutations in the various types of human cancer. Last but not least, cell and molecular biology studies are mandatory to understand the role(s) of telomerase in cancer cells that appear to go beyond the increased replicative potential (immortalization) and have impact also in metastatic capacities.

\section{References}

1. Allory $Y$, Beukers $W$, Sagrera $A$, Flandez $M$, Marques $M$, Marquez $M$, van der Keur KA, Dyrskjot L, Lurkin I, Vermeij M, Carrato A, Lloreta J, Lorente JA, Carrillo-de Santa Pau E, Masius RG, Kogevinas M, Steyerberg EW, van Tilborg AA, Abas C, Orntoft TF, Zuiverloon TC, Malats N, Zwarthoff EC, Real FX (2014) Telomerase reverse transcriptase promoter mutations in bladder cancer: high frequency across stages, detection in urine, and lack of association with outcome. Eur Urol 65:360-366. doi:10.1016/j. eururo.2013.08.052

2. Anic GM, Sondak VK, Messina JL, Fenske NA, Zager JS, Cherpelis BS, Lee JH, Fulp WJ, Epling-Burnette PK, Park JY, Rollison DE (2013) Telomere length and risk of melanoma, squamous cell carcinoma, and basal cell carcinoma. Cancer Epidemiol 37:434-439. doi:10.1016/j.canep.2013.02.010

3. Arita H, Narita Y, Fukushima S, Tateishi K, Matsushita Y, Yoshida A, Miyakita Y, Ohno M, Collins VP, Kawahara N, Shibui S, Ichimura K (2013) Upregulating mutations in the TERT promoter commonly occur in adult malignant gliomas and are strongly associated with total 1p19q loss. Acta Neuropathol 126:267-276. doi: 10.1007/s00401-013-1141-6

4. Aubert G, Lansdorp PM (2008) Telomeres and aging. Physiol Rev 88:557-579. doi:10.1152/physrev.00026.2007

5. Baerlocher GM, Vulto I, de Jong G, Lansdorp PM (2006) Flow cytometry and FISH to measure the average length of telomeres (flow FISH). Nat Protoc 1:2365-2376. doi:10. 1038/nprot.2006.263

6. Bagheri S, Nosrati M, Li S, Fong S, Torabian S, Rangel J, Moore DH, Federman S, Laposa RR, Baehner FL, Sagebiel RW, Cleaver JE, Haqq C, Debs RJ, Blackburn EH, Kashani-Sabet M (2006) Genes and pathways downstream of telomerase in melanoma metastasis. Proc Natl Acad Sci U S A 103:11306-11311. doi:10.1073/ pnas.0510085103

7. Baird DM, Rowson J, Wynford-Thomas D, Kipling D (2003) Extensive allelic variation and ultrashort telomeres in senescent human cells. Nat Genet 33:203-207. doi:10.1038/ng1084 
8. Bataille V, Kato BS, Falchi M, Gardner J, Kimura M, Lens M, Perks U, Valdes AM, Bennett DC, Aviv A, Spector TD (2007) Nevus size and number are associated with telomere length and represent potential markers of a decreased senescence in vivo. Cancer Epidemiol Biomarkers Prev Publ Am Assoc Cancer Res Cosponsored Am Soc Prev Oncol 16:1499-1502. doi:10.1158/ 1055-9965.EPI-07-0152

9. Blackburn EH (1991) Structure and function of telomeres. Nature 350:569-573. doi:10.1038/350569a0

10. Brennan CW, Verhaak RG, McKenna A, Campos B, Noushmehr H, Salama SR, Zheng S, Chakravarty D, Sanborn JZ, Berman SH, Beroukhim R, Bernard B, Wu CJ, Genovese G, Shmulevich I, Barnholtz-Sloan J, Zou L, Vegesna R, Shukla SA, Ciriello G, Yung WK, Zhang W, Sougnez C, Mikkelsen T, Aldape K, Bigner DD, Van Meir EG, Prados M, Sloan A, Black KL, Eschbacher J, Finocchiaro G, Friedman W, Andrews DW, Guha A, lacocca M, O'Neill BP, Foltz G, Myers J, Weisenberger DJ, Penny R, Kucherlapati R, Perou CM, Hayes DN, Gibbs R, Marra M, Mills GB, Lander E, Spellman P, Wilson R, Sander C, Weinstein J, Meyerson M, Gabriel S, Laird PW, Haussler D, Getz G, Chin L, Network TR (2013) The somatic genomic landscape of glioblastoma. Cell 155:462-477. doi:10.1016/j.cell.2013.09.034

11. Buckingham EM, Klingelhutz AJ (2011) The role of telomeres in the ageing of human skin. Exp Dermatol 20:297-302. doi:10.1111/j. 1600-0625.2010.01242.x

12. Burke LS, Hyland PL, Pfeiffer RM, Prescott J, Wheeler W, Mirabello L, Savage SA, Burdette L, Yeager M, Chanock S, De Vivo I, Tucker MA, Goldstein AM, Yang XR (2013) Telomere length and the risk of cutaneous malignant melanoma in melanoma-prone families with and without CDKN2A mutations. PLoS One 8:e71121. doi:10.1371/journal.pone.0071121

13. Buseman CM, Wright WE, Shay JW (2012) Is telomerase a viable target in cancer? Mutat Res 730:90-97. doi:10.1016/j.mrfmmm. 2011.07.006

14. Cantara S, Pisu M, Frau DV, Caria P, Dettori T, Capezzone M, Capuano S, Vanni R, Pacini F (2012) Telomere abnormalities and chromosome fragility in patients affected by familial papillary thyroid cancer. J Clin Endocrinol Metab 97:E1327-E1331. doi:10. 1210/jc.2011-2096

15. Capezzone M, Cantara S, Marchisotta S, Busonero G, Formichi C, Benigni M, Capuano S, Toti P, Pazaitou-Panayiotou K, Caruso G, Carli AF, Palummo N, Pacini F (2011) Telomere length in neoplastic and nonneoplastic tissues of patients with familial and sporadic papillary thyroid cancer. J Clin Endocrinol Metab 96:E1852-E1856. doi:10.1210/jc.20111003

16. 16. Capezzone M, Marchisotta S, Cantara S, Pacini F (2009) Telomeres and thyroid cancer. Curr Genom 10:526-533. doi:10.2174/ 138920209789503897

17. Carroll KA, Ly H (2009) Telomere dysfunction in human diseases: the long and short of it! Int J Clin Exp Pathol 2: 528-543

18. Carvalho L, Lipay M, Belfort F, Santos I, Andrade J, Haddad A, Brunstein F, Ferreira L (2006) Telomerase activity in prognostic histopathologic features of melanoma. J Plast Reconstr Aesthet Surg JPRAS 59:961-968. doi:10.1016/j.bjps.2006.01.022

19. Castelo-Branco P, Choufani S, Mack S, Gallagher D, Zhang C, Lipman T, Zhukova N, Walker EJ, Martin D, Merino D, Wasserman JD, Elizabeth C, Alon N, Zhang L, Hovestadt V, Kool M, Jones DT, Zadeh G, Croul S, Hawkins C, Hitzler J, Wang JC, Baruchel S, Dirks PB, Malkin D, Pfister S, Taylor MD, Weksberg R, Tabori U (2013) Methylation of the TERT promoter and risk stratification of childhood brain tumours: an integrative genomic and molecular study. Lancet Oncol 14:534-542. doi:10.1016/S1470- 2045(13)70110-4 
20. Cawthon RM (2002) Telomere measurement by quantitative PCR. Nucleic Acids Res 30:e47

21. Cesare AJ, Reddel RR (2010) Alternative lengthening of telomeres: models, mechanisms and implications. Nat Rev Genet 11:319-330. doi:10.1038/nrg2763

22. Cifuentes-Rojas C, Shippen DE (2012) Telomerase regulation. Mutat Res 730:20-27. doi:10.1016/j.mrfmmm.2011.10.003

23. Cong YS, Wen J, Bacchetti S (1999) The human telomerase catalytic subunit hTERT: organization of the gene and characterization of the promoter. Hum Mol Genet 8:137142

24. Damm K, Hemmann U, Garin-Chesa P, Hauel N, Kauffmann I, Priepke H, Niestroj C, Daiber C, Enenkel B, Guilliard B, Lauritsch I, Muller E, Pascolo E, Sauter G, Pantic M, Martens UM, Wenz C, Lingner J, Kraut N, Rettig WJ, Schnapp A (2001) A highly selective telomerase inhibitor limiting human cancer cell proliferation. EMBO J 20:6958-6968. doi:10. 1093/emboj/20.24.6958

25. Dono M, Angelini G, Cecconi M, Amaro A, Esposito Al, Mirisola V, Maric I, Lanza F, Nasciuti F, Viaggi S, Gualco M, Bandelloni R, Truini M, Coviello DA, Zupo S, Mosci C, Pfeffer $U$ (2014) Mutation frequencies of GNAQ, GNA11, BAP1, SF3B1, EIF1AX and TERT in uveal melanoma: detection of an activating mutation in the TERT gene promoter in a single case of uveal melanoma. Br J Cancer. doi:10.1038/bjc. 2013.804

26. Du HY, Pumbo E, Ivanovich J, An P, Maziarz RT, Reiss UM, Chirnomas D, Shimamura A, Vlachos A, Lipton JM, Goyal RK, Goldman F, Wilson DB, Mason PJ, Bessler M (2009) TERC and TERT gene mutations in patients with bone marrow failure and the significance of telomere length measurements. Blood 113:309-316. doi:10.1182/blood-2008-07166421

27. Egberts F, Kruger S, Behrens HM, Bergner I, Papaspyrou G, Werner JA, Alkatout I, Haag J, Hauschild A, Rocken C (2014) Melanomas of unknown primary frequently harbor TERT-promoter mutations. Melanoma Res. doi:10.1097/CMR.0000000000000048

28. El-Daly H, Kull M, Zimmermann S, Pantic M, Waller CF, Martens UM (2005) Selective cytotoxicity and telomere damage in leukemia cells using the telomerase inhibitor BIBR1532. Blood 105:1742-1749. doi:10.1182/blood-2003-12-4322

29. Fabricius EVH, Raguse JR (2012) Molecular biology of basal cell carcinoma. In: Chapter 2, in Basal Cell Carcinoma, Madan, V (Ed.), published by InTech, Rijeka, Croatia, pp 1954

30. Folini M, Colella G, Villa R, Lualdi S, Daidone MG, Zaffaroni N (2000) Inhibition of telomerase activity by a hammerhead ribozyme targeting the RNA component of telomerase in human melanoma cells. J Investig Dermatol 114:259-267. doi:10.1046/j.1523-1747. 2000.00870.x

31. Garcia CK, Wright WE, Shay JW (2007) Human diseases of telomerase dysfunction: insights into tissue aging. Nucleic Acids Res 35:7406-7416. doi:10.1093/nar/gkm644

32. Glaessl A, Bosserhoff AK, Buettner R, Hohenleutner U, Landthaler M, Stolz W (1999) Increase in telomerase activity during progression of melanocytic cells from melanocytic naevi to malignant melanomas. Arch Dermatol Res 291:81-87

33. Gonzalez-Suarez E, Samper E, Ramirez A, Flores JM, MartinCaballero J, Jorcano JL, Blasco MA (2001) Increased epidermal tumors and increased skin wound healing in transgenic mice overexpressing the catalytic subunit of telomerase, mTERT, in basal keratinocytes. EMBO J 20:2619-2630. doi:10.1093/emboj/20.11. 2619 
34. Goutagny S, Nault JC, Mallet M, Henin D, Rossi JZ, Kalamarides M (2013) High Incidence of activating tert promoter mutations in meningiomas undergoing malignant progression. Brain Pathol. doi: 10.1111/bpa.12110

35. Gramatges MM, Bertuch AA (2013) Short telomeres: from dyskeratosis congenita to sporadic aplastic anemia and malignancy. Transl Res J Lab Clin Med 162:353-363. doi:10.1016/j.trsl.2013. 05.003

36. Greider CW (1991) Telomerase is processive. Mol Cell Biol 11: 4572-4580

37. Griewank KG, Murali R, Schilling B, Schimming T, Moller I, Moll I, Schwamborn M, Sucker A, Zimmer L, Schadendorf D, Hillen U (2013) TERT promoter mutations are frequent in cutaneous basal cell carcinoma and squamous cell carcinoma. PLoS One 8:e80354. doi:10.1371/journal.pone.0080354

38. Griewank KG, Murali R, Schilling B, Scholz S, Sucker A, Song M, Susskind D, Grabellus F, Zimmer L, Hillen U, Steuhl KP, Schadendorf D, Westekemper H, Zeschnigk M (2013) TERT promoter mutations in ocular melanoma distinguish between conjunctival and uveal tumours. Br J Cancer 109:497-501. doi:10.1038/bjc.2013.312

39. Griewank KG, Schilling B, Murali R, Bielefeld N, Schwamborn M, Sucker A, Zimmer L, Hillen U, Schaller J, Brenn T, Schadendorf D, Mentzel T (2013) TERT promoter mutations are frequent in atypical fibroxanthomas and pleomorphic dermal sarcomas. Mod Pathol Off J U S Can Acad Pathol Inc. doi:10.1038/modpathol.2013.168

40. Gross TJ, Hunninghake GW (2001) Idiopathic pulmonary fibrosis. N Engl J Med 345:517525. doi:10.1056/NEJMra003200

41. Gunes C, Rudolph KL (2013) The role of telomeres in stem cells and cancer. Cell 152:390393. doi:10.1016/j.cell.2013.01.010

42. Han J, Qureshi AA, Prescott J, Guo Q, Ye L, Hunter DJ, De Vivo I (2009) A prospective study of telomere length and the risk of skin cancer. J Investig Dermatol 129:415-421. doi:10.1038/jid.2008.238

43. Harle-Bachor C, Boukamp P (1996) Telomerase activity in the regenerative basal layer of the epidermis inhuman skin and in immortal and carcinoma-derived skin keratinocytes. Proc Natl Acad Sci U S A 93:6476-6481

44. Hayflick L, Moorhead PS (1961) The serial cultivation of human diploid cell strains. Exp Cell Res 25:585-621

45. Heaphy CM, de Wilde RF, Jiao Y, Klein AP, Edil BH, Shi C, Bettegowda C, Rodriguez FJ, Eberhart CG, Hebbar S, Offerhaus GJ, McLendon R, Rasheed BA, He Y, Yan H, Bigner DD, ObaShinjo SM, Marie SK, Riggins GJ, Kinzler KW, Vogelstein B, Hruban RH, Maitra A, Papadopoulos N, Meeker AK (2011) Altered telomeres in tumors with ATRX and DAXX mutations. Science 333:425. doi:10.1126/science.1207313

46. Heaphy CM, Subhawong AP, Hong SM, Goggins MG, Montgomery EA, Gabrielson E, Netto GJ, Epstein JI, Lotan TL, Westra WH, Shih le M, lacobuzio-Donahue CA, Maitra A, Li QK, Eberhart CG, Taube JM, Rakheja D, Kurman RJ, Wu TC, Roden RB, Argani P, De Marzo AM, Terracciano L, Torbenson M, Meeker AK (2011) Prevalence of the alternative lengthening of telomeres telomere maintenance mechanism in human cancer subtypes. Am J Pathol 179:1608-1615. doi:10.1016/j.ajpath.2011.06.018

47. 47. Heidenreich B, Nagore E, Rachakonda PS, Garcia-Casado Z, Requena C, Traves V, Becker J, Soufir N, Hemminki K, Kumar R (2014) Telomerase reverse transcriptase promoter mutations in primary cutaneous melanoma. Nat Commun 5:3401. doi:10.1038/ncomms4401

48. Henson JD, Hannay JA, McCarthy SW, Royds JA, Yeager TR, Robinson RA, Wharton SB, Jellinek DA, Arbuckle SM, Yoo J, Robinson BG, Learoyd DL, Stalley PD, Bonar SF, Yu D, 
Pollock RE, Reddel RR (2005) A robust assay for alternative lengthening of telomeres in tumors shows the significance of alternative lengthening of telomeres in sarcomas and astrocytomas. Clin Cancer Res Off J Am Assoc Cancer Res 11:217-225

49. Hiraga S, Ohnishi T, Izumoto S, Miyahara E, Kanemura Y, Matsumura H, Arita N (1998) Telomerase activity and alterations in telomere length in human brain tumors. Cancer Res 58:2117- 2125

50. Horn S, Figl A, Rachakonda PS, Fischer C, Sucker A, Gast A, Kadel S, Moll I, Nagore E, Hemminki K, Schadendorf D, Kumar R (2013) TERT promoter mutations in familial and sporadic melanoma. Science 339:959-961. doi:10.1126/science.1230062

51. Hreidarsson S, Kristjansson K, Johannesson G, Johannsson JH (1988) A syndrome of progressive pancytopenia with microcephaly, cerebellar hypoplasia and growth failure. Acta Paediatr Scand 77: 773-775

52. Hu S, Chan HL, Chen MC, Pang JH (2002) Telomerase expression in benign and malignant skin neoplasms: comparison of three major subunits. J Formos Med Assoc Taiwan Yi Zhi 101:593-597

53. Huang FW, Hodis E, Xu MJ, Kryukov GV, Chin L, Garraway LA (2013) Highly recurrent TERT promoter mutations in human melanoma. Science 339:957-959. doi:10.1126/science.1229259

54. Hurst CD, Platt FM, Knowles MA (2014) Comprehensive mutation analysis of the TERT promoter in bladder cancer and detection of mutations in voided urine. Eur Urol 65:367-369. doi:10.1016/j. eururo.2013.08.057

55. Jendrzejewski J, Tomsic J, Lozanski G, Labanowska J, He H, Liyanarachchi S, Nagy R, Ringel MD, Kloos RT, Heerema NA, de la Chapelle A (2011) Telomere length and telomerase reverse transcriptase gene copy number in patients with papillary thyroid carcinoma. J Clin Endocrinol Metab 96:E1876-E1880. doi:10. 1210/jc.2011-1643

56. Jiao Y, Killela PJ, Reitman ZJ, Rasheed AB, Heaphy CM, de Wilde RF, Rodriguez FJ, Rosemberg S, Oba-Shinjo SM, Nagahashi Marie SK, Bettegowda C, Agrawal N, Lipp E, Pirozzi C, Lopez G, He Y, Friedman H, Friedman AH, Riggins GJ, Holdhoff M, Burger $P$, McLendon R, Bigner DD, Vogelstein B, Meeker AK, Kinzler KW, Papadopoulos N, Diaz LA, Yan H (2012) Frequent ATRX, CIC, FUBP1 and IDH1 mutations refine the classification of malignant gliomas. Oncotarget 3:709-722

57. Killela PJ, Pirozzi CJ, Healy P, Reitman ZJ, Lipp E, Rasheed BA, Yang R, Diplas BH, Wang Z, Greer PK, Zhu H, Wang CY, Carpenter AB, Friedman H, Friedman AH, Keir ST, He J, He Y, McLendon RE, Herndon JE, 2nd, Yan H, Bigner DD (2014) Mutations in IDH1, IDH2, and in the TERT promoter define clinically distinct subgroups of adult malignant gliomas. Oncotarget 5:1515-1525

58. Killela PJ, Reitman ZJ, Jiao Y, Bettegowda C, Agrawal N, Diaz LA Jr, Friedman AH, Friedman H, Gallia GL, Giovanella BC, Grollman AP, He TC, He Y, Hruban RH, Jallo GI, Mandahl N, Meeker AK, Mertens F, Netto GJ, Rasheed BA, Riggins GJ, Rosenquist TA, Schiffman $M$, Shih le $M$, Theodorescu $D$, Torbenson MS, Velculescu VE, Wang TL, Wentzensen N, Wood LD, Zhang M, McLendon RE, Bigner DD, Kinzler KW, Vogelstein B, Papadopoulos N, Yan H (2013) TERT promoter mutations occur frequently in gliomas and a subset of tumors derived from cells with low rates of self-renewal. Proc Natl Acad Sci U S A 110:6021-6026. doi:10.1073/pnas.1303607110

59. Kim NW, Piatyszek MA, Prowse KR, Harley CB, West MD, Ho PL, Coviello GM, Wright WE, Weinrich SL, Shay JW (1994) Specific association of human telomerase activity with immortal cells and cancer. Science 266:2011-2015 
60. Kimura M, Stone RC, Hunt SC, Skurnick J, Lu X, Cao X, Harley CB, Aviv A (2010) Measurement of telomere length by the Southern blot analysis of terminal restriction fragment lengths. Nat Protoc 5:1596-1607. doi:10.1038/nprot.2010.124

61. Kinde I, Munari E, Faraj SF, Hruban RH, Schoenberg M, Bivalacqua T, Allaf M, Springer S, Wang Y, Diaz LA Jr, Kinzler KW, Vogelstein B, Papadopoulos N, Netto GJ (2013) TERT promoter mutations occur early in urothelial neoplasia and are biomarkers of early disease and disease recurrence in urine. Cancer Res 73:7162-7167. doi:10.1158/00085472.CAN-13-2498

62. Koelsche C, Renner M, Hartmann W, Brandt R, Lehner B, Waldburger N, Alldinger I, Schmitt $T$, Egerer $G$, Penzel $R$, Wardelmann $E$, Schirmacher $P$, von Deimling $A$, Mechtersheimer $G$ (2014) TERT promoter hotspot mutations are recurrent in myxoid liposarcomas but rare in other soft tissue sarcoma entities. J Exp Clin Cancer Res CR 33:33. doi:10.1186/1756-9966-33-33

63. Koelsche C, Sahm F, Capper D, Reuss D, Sturm D, Jones DT, Kool M, Northcott PA, Wiestler B, Bohmer K, Meyer J, Mawrin C, Hartmann C, Mittelbronn M, Platten M, Brokinkel B, Seiz M, Herold-Mende C, Unterberg A, Schittenhelm J, Weller M, Pfister S, Wick W, Korshunov A, von Deimling A (2013) Distribution of TERT promoter mutations in pediatric and adult tumors of the nervous system. Acta Neuropathol 126:907-915. doi:10.1007/ s00401-013-1195-5

64. Kulla E, Katz E (2008) Biosensor Techniques used for determination of telomerase activity in cancer cells. Sensors 8:347-369

65. Kyo S, Takakura M, Fujiwara T, Inoue M (2008) Understanding and exploiting hTERT promoter regulation for diagnosis and treatment of human cancers. Cancer Sci 99:15281538. doi:10.1111/j.1349- 7006.2008.00878.x

66. Landa I, Ganly I, Chan TA, Mitsutake N, Matsuse M, Ibrahimpasic T, Ghossein RA, Fagin JA (2013) Frequent somatic TERT promoter mutations in thyroid cancer: higher prevalence in advanced forms of the disease. J Clin Endocrinol Metab 98:E1562-E1566. doi:10. 1210/jc.2013-2383

67. Langford LA, Piatyszek MA, Xu R, Schold SC Jr, Shay JW (1995) Telomerase activity in human brain tumours. Lancet 346:1267-1268

68. Liang G, Qureshi AA, Guo Q, De Vivo I, Han J (2011) No association between telomere length in peripheral blood leukocytes and the risk of nonmelanoma skin cancer. Cancer Epidemiol Biomark Prev Publ Am Assoc Cancer Res Cosponsored Am Soc Prev Oncol 20:1043-1045. doi:10. 1158/1055-9965.EPI-11-0072

69. Liau JY, Tsai JH, Jeng YM, Chu CY, Kuo KT, Liang CW (2014) TERT promoter mutation is uncommon in acral lentiginous melanoma. J Cutan Pathol. doi:10.1111/cup.12323

70. Lin Y, Miyamoto H, Fujinami K, Uemura H, Hosaka M, Iwasaki Y, Kubota Y (1996) Telomerase activity in human bladder cancer. Clin Cancer Res Off J Am Assoc Cancer Res 2:929-932

71. Lindsey JC, Schwalbe EC, Potluri S, Bailey S, Williamson D, Clifford SC (2014) TERT promoter mutation and aberrant hypermethylation are associated with elevated expression in medulloblastoma and characterise the majority of non-infant SHH subgroup tumours. Acta Neuropathol 127:307-309. doi:10.1007/s00401- 013-1225-3

72. Liu JP, Chen W, Schwarer AP, Li H (2010) Telomerase in cancer immunotherapy. Biochim Biophys Acta 1805:35-42. doi:10.1016/j. bbcan.2009.09.001

73. Liu T, Liang X, Bjorkholm M, Jia J, Xu D (2014) The absence of TERT promoter mutations in primary gastric cancer. Gene 540:266- 267. doi:10.1016/j.gene.2014.02.051 
74. Liu T, Wang N, Cao J, Sofiadis A, Dinets A, Zedenius J, Larsson C, Xu D (2013) The ageand shorter telomere-dependent TERT promoter mutation in follicular thyroid cellderived carcinomas. Oncogene. doi:10.1038/onc.2013.446

75. Liu X, Bishop J, Shan Y, Pai S, Liu D, Murugan AK, Sun H, EINaggar AK, Xing M (2013) Highly prevalent TERT promoter mutations in aggressive thyroid cancers. Endocr Relat Cancer 20: 603-610. doi:10.1530/ERC-13-0210

76. Liu X, Qu S, Liu R, Sheng C, Shi X, Zhu G, Murugan AK, Guan H, Yu H, Wang Y, Sun H, Shan $Z$, Teng $W$, Xing $M$ (2014) TERT promoter mutations and their association with BRAF V600E mutation and aggressive clinicopathological characteristics of thyroid cancer. J Clin Endocrinol Metab. doi:10.1210/jc.2013-4048

77. Liu X, Wu G, Shan Y, Hartmann C, von Deimling A, Xing M (2013) Highly prevalent TERT promoter mutations in bladder cancer and glioblastoma. Cell Cycle 12:1637-1638. doi:10.4161/cc.24662

78. Lotsch D, Ghanim B, Laaber M, Wurm G, Weis S, Lenz S, Webersinke G, Pichler J, Berger W, Spiegl-Kreinecker S (2013) Prognostic significance of telomerase-associated parameters in glioblastoma: effect of patient age. Neuro-Oncology 15:423-432. doi: 10.1093/neuonc/nos329

79. Marrone A, Walne A, Dokal I (2005) Dyskeratosis congenita: telomerase, telomeres and anticipation. Curr Opin Genet Dev 15: 249-257. doi:10.1016/j.gde.2005.04.004

80. Melo M, Rocha AG, Vinagre J, Batista R, Peixoto J, Tavares C, Celestino R, Almeida A, Salgado C, Eloy C, Castro P, Prazeres H, Lima J, Amaro T, Lobo C, Martins MJ, Moura M, Cavaco B, Leite V, Cameselle-Teijeiro JM, Carrilho F, Cavalheiro M, Maximo V, SobrinhoSimoes $M$, Soares $P$ (2014) TERT promoter mutations are a major indicator of poor outcome in differentiated thyroid carcinomas. J Clin Endocrinol Metab. doi:10.1210/jc.2013-3734

81. Miracco C, Pacenti L, Santopietro R, Laurini L, Biagioli M, Luzi P (2000) Evaluation of telomerase activity in cutaneous melanocytic proliferations. Hum Pathol 31:1018-1021. doi:10.1053/hupa.2000. 9779

82. Mocellin S, Pooley KA, Nitti D (2013) Telomerase and the search for the end of cancer. Trends Mol Med 19:125-133. doi:10.1016/j. molmed.2012.11.006

83. Montanaro L, Calienni M, Ceccarelli C, Santini D, Taffurelli M, Pileri S, Trere D, Derenzini M (2008) Relationship between dyskerin expression and telomerase activity in human breast cancer. Cell Oncol Off J Int Soc Cell Oncol 30:483-490

84. Morii A, Komiya A, Okumura A, Fuse H (2010) Telomerase activity in bladder cancer tissue. Exp Ther Med 1:85-88. doi:10. 3892/etm_00000015

85. Murnane JP (2012) Telomere dysfunction and chromosome instability. Mutat Res 730:28-36. doi:10.1016/j.mrfmmm.2011.04.008

86. Nan H, Du M, De Vivo I, Manson JE, Liu S, McTiernan A, Curb JD, Lessin LS, Bonner MR, Guo Q, Qureshi AA, Hunter DJ, Han J (2011) Shorter telomeres associate with a reduced risk of melanoma development. Cancer Res 71:6758-6763. doi:10.1158/0008-5472. CAN-11-1988

87. Nandakumar J, Cech TR (2013) Finding the end: recruitment of telomerase to telomeres. Nat Rev Mol Cell Biol 14:69-82. doi:10. 1038/nrm3505

88. Nault JC, Mallet M, Pilati C, Calderaro J, Bioulac-Sage P, Laurent C, Laurent A, Cherqui D, Balabaud C, Zucman-Rossi J (2013) High frequency of telomerase reverse-transcriptase promoter somatic mutations in hepatocellular carcinoma and preneoplastic lesions. Nat Commun 4:2218. doi:10.1038/ncomms3218 
89. Nonoguchi N, Ohta T, Oh JE, Kim YH, Kleihues P, Ohgaki H (2013) TERT promoter mutations in primary and secondary glioblastomas. Acta Neuropathol 126:931-937. doi:10.1007/s00401- 013-1163-0

90. Okumura A, Mizuno I, Nagakawa O, Fuse H (2004) Telomerase activity is correlated with lower grade and lower stage bladder carcinomas. Int J Urol Off J Japan Urol Assoc 11:1082-1086. doi: 10.1111/j.1442-2042.2004.00960.x

91. Parris CN, Jezzard S, Silver A, MacKie R, McGregor JM, Newbold RF (1999) Telomerase activity in melanoma and non-melanoma skin cancer. $\mathrm{Br} J$ Cancer 79:47-53. doi:10.1038/sj.bjc.6690010

92. Pascolo E, Wenz C, Lingner J, Hauel N, Priepke H, Kauffmann I, Garin-Chesa P, Rettig WJ, Damm K, Schnapp A (2002) Mechanism of human telomerase inhibition by BIBR1532, a synthetic, nonnucleosidic drug candidate. J Biol Chem 277:15566-15572. doi:10. 1074/jbc.M201266200

93. Perrem K, Lynch A, Al Nooh F, Leader M, Elaine K (2008) The different telomere lengths in basal and squamous cell carcinomas also differ between the nontransplant and renal transplant population. Hum Pathol 39:1034-1041. doi:10. 1016/j.humpath.2007.11.008

94. Populo H, Boaventura P, Vinagre J, Batista R, Mendes A, Caldas R, Pardal J, Azevedo F, Honavar M, Guimaraes I, Manuel Lopes J, Sobrinho-Simoes M, Soares P (2014) TERT Promoter mutations in skin cancer: the effects of sun exposure and X-irradiation. J Investig Dermatol. doi:10.1038/jid.2014.163

95. Preto A, Cameselle-Teijeiro J, Moldes-Boullosa J, Soares P, Cameselle-Teijeiro JF, Silva P, Reis-Filho JS, Reyes-Santias RM, Alfonsin-Barreiro N, Forteza J, Sobrinho-Simoes M (2004) Telomerase expression and proliferative activity suggest a stem cell role for thyroid solid cell nests. Mod Pathol Off J U S Can Acad Pathol Inc 17:819-826. doi:10.1038/modpathol.3800124

96. Prud'homme GJ (2005) DNA vaccination against tumors. J Gene Med 7:3-17. doi:10.1002/jgm.669

97. Qu Y, Dang S, Wu K, Shao Y, Yang Q, Ji M, Shi B, Hou P (2014) TERT promoter mutations predict worse survival in laryngeal cancer patients. Int J Cancer. doi:10.1002/ijc.28728

98. Qu Y, Shi L, Wang D, Zhang B, Yang Q, Ji M, Shi B, Hou P (2013) Low frequency of TERT promoter mutations in a large cohort of gallbladder and gastric cancers. Int J Cancer. doi:10.1002/ijc. 28633

99. Rachakonda PS, Hosen I, de Verdier PJ, Fallah M, Heidenreich B, Ryk C, Wiklund NP, Steineck G, Schadendorf D, Hemminki K, Kumar R (2013) TERT promoter mutations in bladder cancer affect patient survival and disease recurrence through modification by a common polymorphism. Proc Natl Acad Sci U S A 110:17426- 17431. doi:10.1073/pnas.1310522110

100. Ramirez RD, D'Atri S, Pagani E, Faraggiana T, Lacal PM, Taylor RS, Shay JW (1999) Progressive increase in telomerase activity from benign melanocytic conditions to malignant melanoma. Neoplasia 1:42-49

101. Reis-Filho JS, Preto A, Soares P, Ricardo S, Cameselle-Teijeiro J, Sobrinho-Simoes $M$ (2003) p63 expression in solid cell nests of the thyroid: further evidence for a stem cell origin. Mod Pathol Off J U S Can Acad Pathol Inc 16:43-48. doi:10.1097/01.MP.0000047306. 72278.39

102. Remke M, Ramaswamy V, Peacock J, Shih DJ, Koelsche C, Northcott PA, Hill N, Cavalli FM, Kool M, Wang X, Mack SC, Barszczyk M, Morrissy AS, Wu X, Agnihotri S, Luu B, Jones DT, Garzia L, Dubuc AM, Zhukova N, Vanner R, Kros JM, French PJ, Van Meir EG, Vibhakar R, Zitterbart K, Chan JA, Bognar L, Klekner A, Lach B, Jung S, Saad AG, Liau LM, 
Albrecht S, Zollo M, Cooper MK, Thompson RC, Delattre OO, Bourdeaut F, Doz FF, Garami M, Hauser P, Carlotti CG, Van Meter TE, Massimi L, Fults D, Pomeroy SL, Kumabe T, Ra YS, Leonard JR, Elbabaa SK, Mora J, Rubin JB, Cho YJ, McLendon RE, Bigner DD, Eberhart CG, Fouladi M, Wechsler-Reya RJ, Faria CC, Croul SE, Huang A, Bouffet E, Hawkins CE, Dirks PB, Weiss WA, Schuller U, Pollack IF, Rutkowski S, Meyronet D, Jouvet A, FevreMontange M, Jabado N, Perek-Polnik M, Grajkowska WA, Kim SK, Rutka JT, Malkin D, Tabori U, Pfister SM, Korshunov A, von Deimling A, Taylor MD (2013) TERT promoter mutations are highly recurrent in $\mathrm{SHH}$ subgroup medulloblastoma. Acta Neuropathol 126:917-929. doi:10.1007/s00401-013-1198-2

103. Ruden M, Puri N (2013) Novel anticancer therapeutics targeting telomerase. Cancer Treat Rev 39:444-456. doi:10.1016/j.ctrv.2012. 06.007

104. Rudolph P, Schubert C, Tamm S, Heidorn K, Hauschild A, Michalska I, Majewski S, Krupp G, Jablonska S, Parwaresch R (2000) Telomerase activity in melanocytic lesions: a potential marker of tumor biology. Am J Pathol 156:1425-1432. doi:10.1016/ S00029440(10)65011-0

105. Saleh S, King-Yin Lam A, Gertraud Buettner P, Glasby M, Raasch B, Ho YH (2007) Telomerase activity of basal cell carcinoma in patients living in North Queensland, Australia. Hum Pathol 38: 1023-1029. doi:10.1016/j.humpath.2006.12.006

106. Sano T, Asai A, Mishima K, Fujimaki T, Kirino T (1998) Telomerase activity in 144 brain tumours. Br J Cancer 77:1633-1637

107. Savage SA, Bertuch AA (2010) The genetics and clinical manifestations of telomere biology disorders. Genet Med Off J Am Coll Med Genet 12:753-764. doi:10.1097/GIM.0b013e3181f415b5

108. Savage SA, Giri N, Baerlocher GM, Orr N, Lansdorp PM, Alter BP (2008) TINF2, a component of the shelterin telomere protection complex, is mutated in dyskeratosis congenita. Am J Hum Genet 82:501-509. doi:10.1016/j.ajhg.2007.10.004

109. Scheinberg P, Young NS (2012) How I treat acquired aplastic anemia. Blood 120:1185-1196. doi:10.1182/blood-2011-12- 274019

110. Scott GA, Laughlin TS, Rothberg PG (2013) Mutations of the TERT promoter are common in basal cell carcinoma and squamous cell carcinoma. Mod Pathol Off J U S Can Acad Pathol Inc. doi:10. 1038/modpathol.2013.167

111. Shay JW, Bacchetti S (1997) A survey of telomerase activity in human cancer. Eur J Cancer 33:787-791. doi:10.1016/S0959-8049(97)00062-2

112. Shete S, Hosking FJ, Robertson LB, Dobbins SE, Sanson M, Malmer B, Simon M, Marie Y, Boisselier B, Delattre JY, HoangXuan K, El Hallani S, Idbaih A, Zelenika D, Andersson $U$, Henriksson R, Bergenheim AT, Feychting M, Lonn S, Ahlbom A, Schramm J, Linnebank M, Hemminki K, Kumar R, Hepworth SJ, Price A, Armstrong G, Liu Y, Gu X, Yu R, Lau C, Schoemaker M, Muir K, Swerdlow A, Lathrop M, Bondy M, Houlston RS (2009) Genome-wide association study identifies five susceptibility loci for glioma. Nat Genet 41:899-904. doi:10.1038/ng.407

113. Skvortsov DA, Zvereva ME, Shpanchenko OV, Dontsova OA (2011) Assays for detection of telomerase activity. Acta Nat 3:48-68

114. Soares P, Lima J, Preto A, Castro P, Vinagre J, Celestino R, Couto JP, Prazeres H, Eloy C, Maximo V, Sobrinho-Simoes M (2011) Genetic alterations in poorly differentiated and undifferentiated thyroid carcinomas. Curr Genom 12:609-617. doi:10.2174/ 138920211798120853

115. Svenson U, Roos G (2009) Telomere length as a biological marker in malignancy. Biochim Biophys Acta 1792:317-323. doi:10.1016/ j.bbadis.2009.01.017 
116. Szostak JW, Blackburn EH (1982) Cloning yeast telomeres on linear plasmid vectors. Cell 29:245-255

117. Tallet A, Nault JC, Renier A, Hysi I, Galateau-Salle F, Cazes A, Copin MC, Hofman P, Andujar P, Le Pimpec-Barthes F, Zucman-Rossi J, Jaurand MC, Jean D (2013) Overexpression and promoter mutation of the TERT gene in malignant pleural mesothelioma. Oncogene. doi:10.1038/onc.2013.351

118. Taylor RS, Ramirez RD, Ogoshi M, Chaffins M, Piatyszek MA, Shay JW (1996) Detection of telomerase activity in malignant and nonmalignant skin conditions. J Investig Dermatol 106:759-765

119. Ueda M, Ouhtit A, Bito T, Nakazawa K, Lubbe J, Ichihashi M, Yamasaki H, Nakazawa H (1997) Evidence for UV-associated activation of telomerase in human skin. Cancer Res 57:370-374

120. van Nistelrooij AM, Zwarthoff EC, Post E, Lurkin I, van Marion R, Kopershoek E, Biermann K, Wijnhoven BP, Dinjens WN (2013) Absence of TERT promoter mutations in esophageal adenocarcinoma. Int J Cancer. doi:10.1002/ijc.28527

121. Vinagre J, Almeida A, Populo H, Batista R, Lyra J, Pinto V, Coelho R, Celestino R, Prazeres H, Lima L, Melo M, da Rocha AG, Preto A, Castro P, Castro L, Pardal F, Lopes JM, Santos LL, Reis RM, Cameselle-Teijeiro J, Sobrinho-Simoes M, Lima J, Maximo V, Soares P (2013) Frequency of TERT promoter mutations in human cancers. Nat Commun 4:2185. doi:10.1038/ncomms3185

122. Vonderheide RH, Domchek SM, Schultze JL, George DJ, Hoar KM, Chen DY, Stephans KF, Masutomi K, Loda M, Xia Z, Anderson KS, Hahn WC, Nadler LM (2004) Vaccination of cancer patients against telomerase induces functional antitumor CD8+ $T$ lymphocytes. Clin Cancer Res Off J Am Assoc Cancer Res 10:828- 839

123. Wang K, Liu T, Liu L, Liu J, Liu C, Wang C, Ge N, Ren H, Yan K, Hu S, Bjorkholm M, Fan Y, Xu D (2014) TERT promoter mutations in renal cell carcinomas and upper tract urothelial carcinomas. Oncotarget 5:1829-1836

124. Wu RC, Ayhan A, Maeda D, Kim KR, Clarke BA, Shaw P, Chui MH, Rosen B, Shih le $M$, Wang TL (2014) Frequent somatic mutations of the telomerase reverse transcriptase promoter in ovarian clear cell carcinoma but not in other major types of gynaecological malignancy. J Pathol 232:473-481. doi:10.1002/ path.4315

125. Wu S, Huang P, Li C, Huang Y, Li X, Wang Y, Chen C, Lv Z, Tang A, Sun X, Lu J, Li W, Zhou J, Gui Y, Zhou F, Wang D, Cai Z (2014) Telomerase reverse transcriptase gene promoter mutations help discern the origin of urogenital tumors: a genomic and molecular study. Eur Urol 65:274-277. doi:10.1016/j.eururo.2013.10.038

126. Yang CH, Hung WC, Wang SL, Kang WY, Chen WT, Huang YC, Su YC, Chai CY (2008) Immunoexpression and prognostic role of hTERT and cyclin D1 in urothelial carcinoma. APMIS Acta Pathol Microbiol Immunol Scand 116:309-316. doi:10.1111/j.1600-0463. 2008.00905.x

127. Zhao Y, Chen G, Zhao Y, Song X, Chen H, Mao Y, Lu D (2012) Fine-mapping of a region of chromosome $5 \mathrm{p} 15.33$ (TERT-CLPTM1L) suggests a novel locus in TERT and a CLPTM1L haplotype are associated with glioma susceptibility in a Chinese population. Int J Cancer 131:1569-1576. doi:10.1002/ijc.27417

128. Zhao Y, Gao Y, Chen Z, Hu X, Zhou F, He J (2013) Low frequency of TERT promoter somatic mutation in 313 sporadic esophageal squamous cell carcinomas. Int J Cancer. doi:10.1002/ijc.28360

129. Zhou X, Xing D (2012) Assays for human telomerase activity: progress and prospects. Chem Soc Rev 41:4643-4656. doi:10. 1039/c2cs35045a 